\title{
Genetic analysis of reproductive development in tomato
}

\author{
RAFAEL LOZANO*,1, ESTELA GIMÉNEZ" ${ }^{1}$ BEATRIZ CARA ${ }^{1, \#, ~ J U A N ~ C A P E L ~}{ }^{1}$ and TRINIDAD ANGOSTO ${ }^{2}$ \\ ${ }^{1}$ Departamento de Biología Aplicada and 2Departamento de Biología Vegetal y Ecología, \\ Universidad de Almería, Almería, Spain
}

\begin{abstract}
Besides being an important commercial crop, tomato (Solanum lycopersicum L.) constitutes a model species for the study of plant developmental processes. Current research tends to combine classic disciplines such as physiology and genetics with modern approaches coming from molecular biology and genomics with a view to elucidating the biological mechanisms underlying plant architecture, floral transition and development of flowers and fruits. Comparative and functional analyses of tomato regulatory genes such as LATERAL SUPPRESSOR (LS), SELF PRUNING (SP), SINGLE FLOWER TRUSS (SFT) and FALSIFLORA (FA) have revealed mechanisms involved in shoot development and flowering time which are conserved among Arabidopsis, tomato and other plant species. Furthermore, several regulatory genes encoding transcription factors have been characterized as responsible for singular features of vegetative and reproductive development of tomato. Thus, the sympodial growth habit seems to require a specific control of the developmental fate followed by shoot meristems. In this process, novel genetic and molecular interactions involving $S P, S F T$ and $F A$ genes would be essential. Also this latter, but mainly ANANTHA (AN) and COMPOUND INFLORESCENCE (S) have recently been found to regulate the inflorescence architecture of the tomato. Concerning fruit development, genetic and molecular analyses of new genes such as fw2.2, FASCIATED, OVATE and SUN have proved their contribution to the domestication process and most importantly, their function as key regulators of fruit size and shape variation. Tomato ripening is also being elucidated thanks to the characterization of regulatory genes such as RIPENING INHIBITOR (RIN), NON-RIPENING (NOR), TDR4 and COLORLESS NON-RIPENING (CNR), which have been found to control early stages of fruit development and maturation. At the same time, much research is dedicated to isolating the targets of the ripening regulators, as well as the key genes promoting the parthenocarpic development of tomato fruits. Hopefully, the ongoing sequencing project and the progress made by integrating several research fields will help to unravel the genetic and molecular pathways controlling tomato development.
\end{abstract}

KEY WORDS: tomato, flowering, fruit development, transcription factor

\section{Introduction}

Tomato is a perennial vegetable which is almost universally cultivated as an annual crop. It belongs to the Solanaceae family as do its close cousins potato, eggplant, pepper, tobacco and petunia. The origins of cultivated tomato can be traced to the Andean region of South America -from Ecuador to Chile- but its native wild species was less attractive in size, shape and colours than the domesticated cultigens taken to Europe in the mid-sixteenth century. Several data point to Mexico as the probable region of domestication and the word "tomatl "in the Nahuatl language of Mexico is undoubtedly the origin of the modern name (Rick, 1978). While morphological descriptions usually made from herbarium material placed wild tomato as belonging to the genus $\angle y c o p e r s i c o n$, a recent study on the tomato variability, including genetic and molecular markers, has shown that it is deeply nested in the Solanum genus, forming the sister clade to potato (Peralta et al., 2005). Therefore, Lycopersicon esculentum Mill. has been renamed Solanum lycopersicum L.

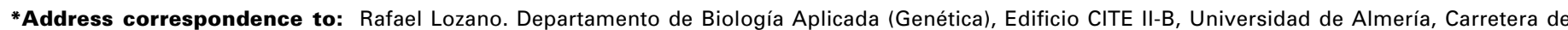
Sacramento s/n, 04120 Almería, Spain. Fax: +34-950-01-5476. e-mail: rlozano@ual.es
}

\#Present address: Centro de Edafología y Biología Aplicada del Segura (CEBAS), CSIC. 3100 Murcia, Spain.

Final author-corrected PDF published online: 11 November 2009.

ISSN: Online 1696-3547, Print 0214-6282

(c) 2009 UBC Press

Printed in Spain 
Thought to be poisonous due to its relationship with belladonna and mandrake, tomato is now a major crop for human consumption. Together with its economic importance, it has also become a model plant for research purposes (Emmanuel and Levy, 2002; Van der Hoeven et al., 2002; Giovannoni, 2007). It is easy to cultivate, has a short life cycle and tends itself to horticultural manipulation including grafting or cutting. Various types of explants can be cultured in vitro and plant regeneration is feasible, allowing efficient transformation procedures. In addition, tomato has several features that distinguish it from other model plant species: it is phylogenetically distant either from maize, Arabidopsis, snapdragon, rice, Medicago or poplar, it contains sequences that share no significant similarity to those from other plant species and it grows as an indeterminate plant due to reiterate switches from vegetative to reproductive stages. Together, genetic research has progressed further than in other crop species, and lately, tomato is the most advanced model among species bearing a fleshy berry type of fruit. Other properties of tomato, such as the small genome size ( $0.9 \mathrm{pg}$ per haploid genome; Arumuganathan and Earle, 1991), the availability of a large set of mutants and the development of genomic and sequencing resources (genetic and physical maps, ESTs and microarrays), have favoured an international sequencing project and are contributing to the current progress in understanding the biological bases of plant development. Extensive details on these topics can be obtained at the following website: http://www.sgn.cornell.edu/.

Noteworthy, tomato mutants constitute not only an essential source of plant material for breeders but also a valuable tool for isolating important genes which regulate developmental patterns of tomato, and whose functional roles are now being elucidated. Many spontaneous mutants are being preserved and characterized by the Tomato Genetic Resource Center (Chetelat, 2005). Also, induced mutations, mainly generated through chemical ethylmethane sulfonate (EMS) and irradiation, are providing available screening populations and the possibility to identify new developmental genes. Exhaustive data about these tomato mutants can be obtained from the following Websites: http://tgrc.ucdavis.edu/ and http:// zamir.sgn.cornell.edu/mutants/. Nevertheless, as few insertional mutants have been described to date, more research is required in approach to facilitate the cloning of tomato genes and unveil their functions and molecular interactions.

\section{Shoot architecture}

For most tomato cultivars the vegetative phase is short; typically 6 to 12 leaves are produced below the first inflorescence and the floral transition usually starts when the third leaf is expanding. Contrary to Arabidopsis thaliana and Antirrhinum majus, which have a monopodial growth pattern, tomato shows a sympodial growth habit. While in monopodial species the shoot apical meristem (SAM) is indeterminate and the vegetative or reproductive organs are generated on its flanks, the SAM of tomato is determinate and the primary shoot is completed by the first inflorescence (Figs. 1 and 2). This first stem fragment is called the "initial segment". A new vegetative shoot then arises from the uppermost (proximal) axillary meristem, i.e. the sympodial meristem located at the axil of the youngest leaf just
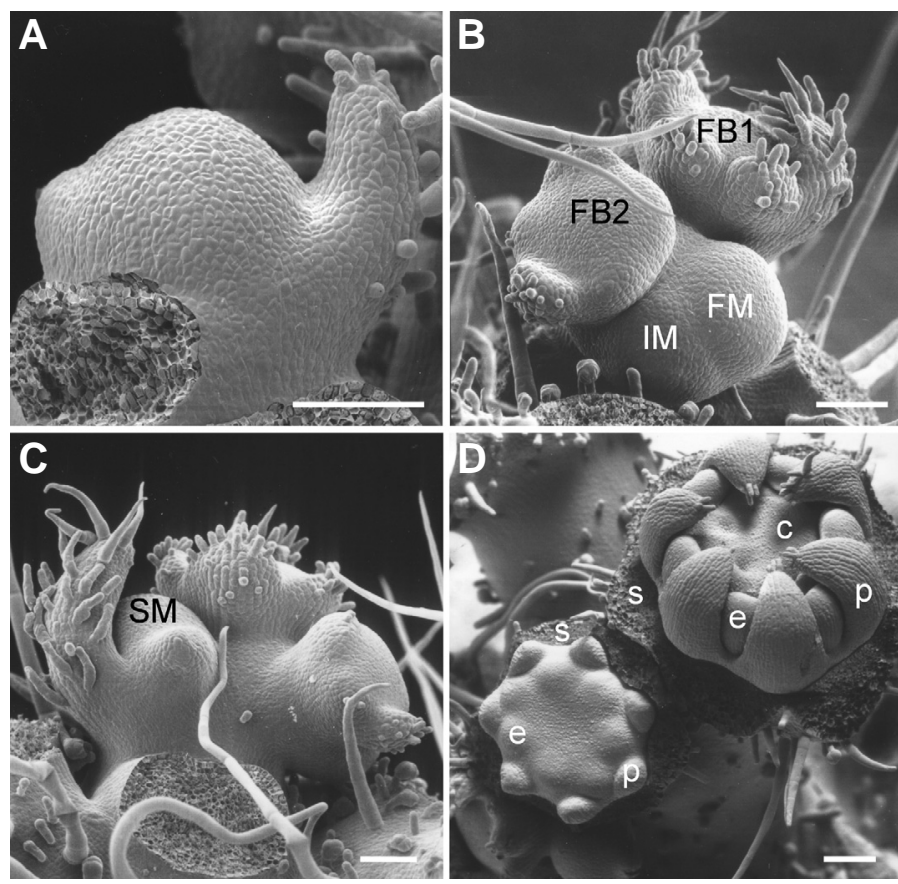

Fig. 1. Development of tomato meristems lanalysed by scanning electron microscopy). The shoot apical meristem (SAM) develops leaf primordia (A). Upon floral transition, the SAM is converted into a reproductive meristem (B), which in turn gives rise to the first floral meristem (FM) and a mound of dividing cells, the latter functioning as an inflorescence meristem (IM). The successive splitting of the IM produces new FMs until the inflorescence development is completed; organ primordia emerging from the floral meristem can be observed in the floral buds (FB). The indeterminate growth of tomato plant occurs by the activity of the sympodial meristem (SM), which is located at the axil of the uppermost leaf (C). Two flower buds at different developmental stages can be observed along the inflorescence (D); they bear organ primordia (s, sepal; p, petal; e, stamen; c, carpel) placed in four consecutive flower whorls (sepal primordia removed). Scale, $100 \mu \mathrm{m}$.

below the terminating inflorescence (Fig. 1C). The sympodial meristem allows the plant to continue its growth carrying up the leaf which, due to the active growth of this bud and the partial fusion of its petiole with the new vegetative shoot, is finally located above the inflorescence. This sympodial shoot forms three vegetative nodes (leaves) and terminates in a new inflorescence. This growth pattern is repeated by the formation of successive determinate units or sympodial segments, resulting from the newly arisen sympodial meristems (see wt phenotype in Fig. 2). Thus, the architecture of a tomato plant means a regular alternation of vegetative and reproductive phases along the primary and axillary shoots (Atherton and Harris, 1986).

Despite the differences between the monopodial and sympodial systems, genes that maintain the indeterminate state of the shoot apex in Arabidopsis, TERMINAL FLOWER 1(TFL 1), and Antirrhinum, CENTRORADIALIS (CEN), have an orthologue in the tomato genome, the SELF PRUNING (SP) gene (Table 1), which controls the regular vegetative-to-reproductive switch of inflorescence meristems (Pnueli et al., 1998). A mutation in $S P$ or the suppression of gene activity by antisense RNA has no effect on the architecture of the initial segment or the flowering time (in terms of node number). However, $s p$ 
mutant allele promotes a gradual reduction in the number of vegetative nodes arising on successive sympodial segments until the vegetative phase is completely by-passed with the development of two consecutive inflorescences (Fig. 2) (Yeager, 1927). Overexpression of $S P$ or $C E N$ in tomato plants results in an extended vegetative phase of sympodial shoots and in an increased leafiness of the inflorescence itself (Pnueli et al., 1998). CEN, TFL 1 and $S P$ are members of a novel family of regulatory genes denominated $C E T S$, which encode a family of modulator/adapter proteins capable of interacting with a variety of signalling proteins. Among the tomato members of this family, SINGLE FLOWER TRUSS (SFT) gene is involved both in the transition to flowering (see the following section) and the shoot development (Lifschitz et al., 2006). In fact, sftmutation arrests the growth of the sympodial buds and allows the plant to grow from the ectopic vegetative meristems appearing in the inflorescence (Kerr, 1982). Therefore, SFT gene is required for the normal development of the sympodial meristem. Reduced expression level of $S P$ in the apical buds of the sft mutant suggests that the function of $S F T$ controlling sympodial development depends on its interaction with $S P$, probably acting as an upstream regulator of $S P$ in the sympodial meristem (Molinero-Rosales et al., 2004).

The formation of lateral branches is regulated by $\angle A T E R A L$ SUPPRESSOR $(\angle S)$ and $B L I N D(B L)$ genes (Fig. 2). While $B L$ affects both sympodial and axillary meristems (Rick and Butler, 1956; Schmitz et al., 2002), $L S$ is only involved in the development of the latter (Malayer and Guard, 1964; Schumacher et al., 1999). Among the phenotypic abnormalities showed by $/ s$ mutant, the lack of lateral meristems during vegetative growth of the initial segment is particularly apparent (Fig. 2). Cloning and characterization of $L S$ has revealed that it encodes a putative transcription factor of the GRAS family to which some negative regulators of gibberellin response also belong (Schumacher et al., 1999). Furthermore, expression of the Arabidopsis orthologous $\angle A S$ gene in the tomato /s mutant restores the wild-type phenotype, indicating a conserved mechanism in the control of axillary meristem initiation (Greb et al., 2003). The $B L$ gene is a member of the R2R3 class of MYB transcription factors involved in the regulation of various bio- logical processes. The phenotype of the double mutant $/ s$ b/ suggests that $B L$ and $\angle S$ participate in different pathways which promote the development of lateral meristems (Schmitz et al., 2002).

\section{Transition to flowering}

In tomato, the transition to flowering means that the apical meristem is completely consumed in the development of the first inflorescence. This process is under control of environmental and endogenous factors, the later being of genetic and hormonal nature. This crop species is considered a day-neutral plant since the time to flowering, as measured by the number of leaves developed before floral transition, is not affected by photoperiod (Kinet and Peet, 1997). In fact, some genes have been identified and characterized as members of an autonomous pathway controlling floral transition. In the initial segment, FALSIFLORA (FA) and SINGLE FLOWER TRUSS(SFT) promote floral transition (Molinero-Rosales etal., 1999; MolineroRosales et al., 2004; Lifschitz et al., 2006), while SPregulates this process in the sympodial segments (Pnueli et al., 1998). Mutations at either $F A$ or $S F T$ loci result in a photoperiodindependent late flowering phenotype and in abnormalities affecting inflorescence development (Fig. 2). $F A$ is orthologous to $\angle E A F Y(\angle F Y)$ and FLORICAULA (FLO), two floral identity genes of Arabidopsis and Antirrhinum, respectively, although only $\angle F Y$ regulates floral transition as $F A$ does (MolineroRosales et al., 1999).

SFTis orthologous to the Arabidopsis FLOWERING LOCUS $T(F T)$ and triggers systemic signals that regulate floral transition and sympodial growth in tomato (Lifschitz et al., 2006). Double mutant sft fais unable to flower suggesting that $F A$ and $S F T$ regulate floral transition by independent pathways. This agrees with the fact that $F A$ expression is not affected by $s f t$ mutation (Molinero-Rosales et al., 2004). In petunia, floral transition is abolished by a single mutation in the PETUNIA FLOWERING GENE (PFG), a MADS-box gene highly homologous to Arabidopsis APETALA1 (AP1) (Immink et al., 1999). Interestingly, $A P 1$ overexpression in tomato caused early flowering with no obvious effects on sympodial development (Ellul

TABLE 1

TOMATO MUTATIONS AFFECTING EITHER INFLORESCENCE OR FLORAL MERISTEM IDENTITY GENES

\begin{tabular}{|c|c|c|c|c|}
\hline Mutant & Phenotype & Isolated gene & References & Arabidopsis orthologue \\
\hline self-pruning $(s p)$ & Altered sympodial meristem development & $S P$ & $\begin{array}{l}\text { Yeager, } 1927 \\
\text { Pnueli et al., } 1998\end{array}$ & TERMINAL FLOWER1 \\
\hline single flower truss (sft) & Late flowering, altered sympodial development & SPD3 (SFT in text) & $\begin{array}{l}\text { Kerr, } 1982 \\
\text { Lifschitz et al., } 2006\end{array}$ & FLOWERING LOCUS T \\
\hline lateral suppressor (Is) & Lack of axillary lateral meristems & LS & $\begin{array}{l}\text { Rick and Butler, } 1956 \\
\text { Schumacher et al. } 1999\end{array}$ & LAS \\
\hline blind $(b)=$ torosa $(t o)$ & Absence of sympodial meristem & $B L$ & $\begin{array}{l}\text { Malayer and Guard, } 1964 \\
\text { Schmitz et al., } 2002\end{array}$ & $R A X \mathrm{R} 2 \mathrm{R} 3 \mathrm{Myb}$ \\
\hline falsiflora (fa) & Late flowering, loss of floral meristem identity & $F A$ & $\begin{array}{l}\text { Stubbe, } 1963 \\
\text { Molinero-Rosales et al., } 1999\end{array}$ & LEAFY \\
\hline uniflora (uf) & Late flowering, inflorescence composed by a single flower & & Dielen et al., 1998 & \\
\hline compound inflorescence $(s)$ & Late flowering, affected inflorescence meristem development & $s$ & $\begin{array}{l}\text { Quinet et al., } 2006 \\
\text { Lippman et al., } 2008\end{array}$ & WOX9/STIMPY \\
\hline anantha $(a n)$ & Highly branched inflorescence, altered floral meristem identity & $A N$ & $\begin{array}{l}\text { Allen and Sussex, } 1996 \\
\text { Lippman et al., } 2008\end{array}$ & $\begin{array}{l}\text { UNUSUAL FLORAL } \\
\text { ORGANS }\end{array}$ \\
\hline jointless $(j)$ & Altered inflorescence meristem identity & $J$ & $\begin{array}{l}\text { Rick and Butler, } 1956 \\
\text { Mao et al., } 2000\end{array}$ & AGL24 \\
\hline
\end{tabular}


et al., 2004). By contrast, mutations of three flowering genes, each involved in a different regulatory pathway, are required to avoid flowering in Arabidopsis (Reeves and Coupland, 2001). The domestication process of petunia (ornamental species) and tomato (crop species) may have favoured a reduction in the number of genes needed to flower by eliminating redundancy in flowering genes. Alternatively, gene interactions controlling floral transition may differ among plant species, yet the functional roles of individual genes may be similar.

Late flowering mutants uniflora (uf) and compound inflorescence $(s)$ (Fig. 2) show enhanced phenotypes under winter conditions, namely low irradiance (daily light energy integral) and poor assimilate availability perceived by the apical meristem. Thus, an environment-dependent pathway also seems to regulate floral transition in tomato (Dielen et al., 1998; Quinet et al., 2006b). As the fa sft double mutant, introducing sft into the uf background completely suppresses floral transition, which suggests that UFand SFTpromote flowering but participating in parallel regulatory pathways (Lifschitz and Eshed, 2006). Although the genetic interactions between UF and $F A$ remain to be clarified, $u f$ is epistatic over most of flowering mutations (Quinet et al. 2006a), indicating that UF is a key regulator of tomato flowering. Moreover, UF might function upstream to $S F T$ as is indicated by the fact that constitutive expression of $S F T$ rescues the flowering time phenotype of the uniflora mutant, substituting its high light requirements (Lifschitz et al., 2006).

$S P$ gene does not affect the time to flowering in the initial segment, since its mutation produces a progressive shortening of the floral transition in the sympodial segments (Pnueli et al., 1998). However, the capability of spallele to rescue the flowering phenotype avoided in the non-flowering double mutants sft fa and sft uf (Lifschitz and Eshed, 2006) agrees with a role of $S P$ in floral induction, which deserves greater attention. Additionally, famutation produces the opposite effect to $s p$, i.e. an increased number of vegetative nodes in the first sympodial segments. This feature, and the expression pattern of $F A$, proves its involvement in sympodial development. Although the function of $S P$ seems to be antagonistic to $F A$, the vegetativeto-reproductive switch in the sympodial segment may depend on a balance between FA and SPtranscription levels (MolineroRosales et al., 1999). Likewise, a balance in the activities of $S F T$ and $S P$ could be responsible for the floral transition of both initial and sympodial segments (Lifschitz and Eshed, 2006). Thus, different developmental scenarios may be possible as result of genetic interactions among flowering genes at the apical and sympodial meristems, which should be further investigated.

Additionally, JOINTLESS $(\mathcal{C})$ and $B L I N D(B L)$ genes seem to promote autonomous flowering in tomato, although the most evident alterations produced by $j$ and $b /$ mutations affect the inflorescence development (Fig. 2). Molecular characterization of these genes and their interactions with meristem identity genes support this functional role (Mao et al., 2000; Schmitz et al., 2002; Szymkowiak and Irish, 2006).

Although tomato flowers autonomously, environmental cues can modify this developmental pattern. Low temperatures (10$15^{\circ} \mathrm{C}$ ) reduce the number of nodes up to the first inflorescence, and also the rate at which these leaves are produced. Similarly, a scarce but significant reduction in flowering time has been observed in many cultivars grown under short day conditions (see Samach and Lotan, 2007). Most importantly, high irradiance accelerates flowering, an effect associated with a higher rate of leaf initiation and an increased assimilate availability in the meristem (Kinet and Peet, 1997; Dielen et al., 2004). Light is perceived by the plant through photoreceptors, particularly red/far red light PHYTOCHROME (PHY) and blue light CRYPTOCHROME (CRY) receptors. Overexpression of tomato $C R Y 2$ does not alter flowering time but does increase the number of days to the first floral anthesis (Giliberto et al., 2005). Interestingly, a QTL mapping approach has revealed that $P H Y 2 B$ gene, as well as FALSIFLORA, co-localize with major QTLs responsible for floral transition in this species, making them candidate genes for the domestication process of tomato (Jiménez-Gómez et al., 2007).

Autonomous flowering of tomato is also modulated by hormones, though their roles during floral transition have been poorly studied. Gibberellins (GAs) promote tomato flowering since GA-deficient mutants require exogenous gibberellins to flower (Koornneef et al., 1990). Elevated GA contents increase the number of leaves before flowering and the rate of leaf initiation (Kinet and Peet, 1997). Furthermore, in vitro experiments show that cytokinin-mediated stimulating effect on floral initiation could be inhibited by GA. Most probably, plant hormones modulate tomato flowering by gene interactions involving several regulatory pathways although the nature of such interactions is still unknown.

Most flowering mutants already characterized in tomato flower later than the corresponding wild type backgrounds. Of forty one flowering mutants identified by an "in silico" screening, only four showed an early flowering phenotype (Menda et al.,
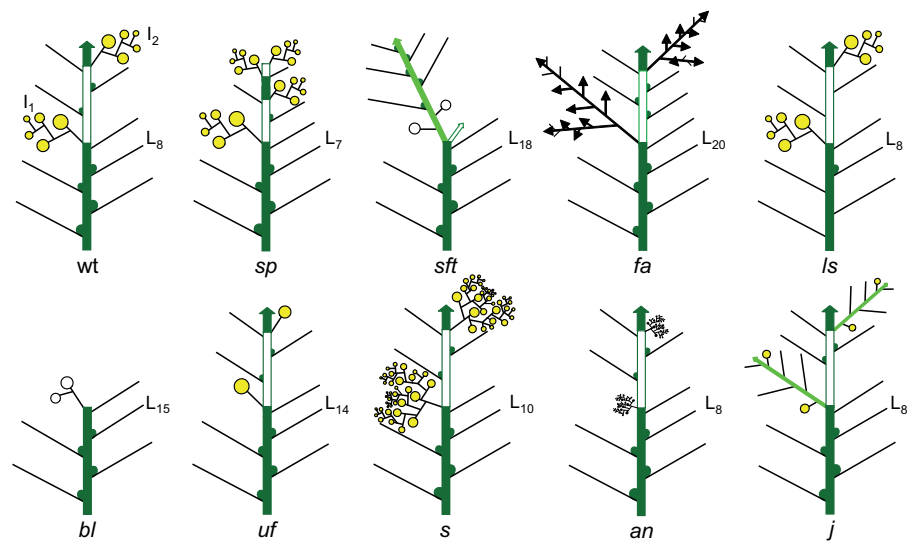

$\begin{array}{ll}1 & \text { Sympodial meristem } \\ \text { Sympodial segment } \\ \text { Flower }\end{array}$

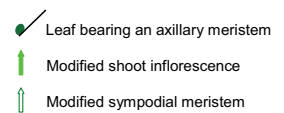

$\bigcirc$ Modified flower

$\nearrow$ Vegetative shoot

- Arrested floral meristem

Fig. 2. Schematic representations of shoot architecture and reproductive structures of wild type (wt) tomato and several mutants altered in floral transition (sft, fa, bl and uf), sympodial growth (sp, sft and bl) and inflorescence/floral development (fa, sft, bl, uf, s, an and j). Note that the wild type genotype used as reference in this paper usually flowers after the formation of seven leaves (L7); however this number may differ in other tomato backgrounds. See text for mutant descriptions. The first vegetative segment (green) is referred as the initial segment in the text; the remaining vegetative segments have a sympodial origin. 
2004). These observations, together with the influence of environmental cues on flowering time, suggest that selection of favourable combinations of flowering genes has played a crucial role throughout the tomato domestication process, enabling early flowering and ensuring fruit yield under several conditions.

\section{Reproductive development}

Tomato inflorescence has been classically described as a cyme, although available evidences also permit to interpret it as a raceme (Quinet and Kinet, 2007; Lippman et al., 2008). Irrespectively, initiation of reproductive development entails the conversion of the apical meristem into an inflorescence meristem (IM) from which the floral meristem is produced laterally, giving rise to the first flower. The successive floral meristems developed from the IM are located at the base of each preceding flower bud. This process culminates in the production of a terminal flower, once the determinate inflorescence is composed of about five to ten flowers (Allen and Sussex, 1996).

\section{Inflorescence and flower initiation}

In tomato, the activity of the inflorescence meristem is affected by $B L$ and $U F$ genes, since the inflorescence is prematurely terminated by a reduced number of flowers in the $\mathrm{b} /$ mutant, or by a single flower in the uf mutant (Rick and Butler, 1956; Fehleisen, 1967; Dielen et al., 1998; Schmitz et al., 2002). The unusual reproductive structure of the $u$ f mutant (Fig. 2) results from its inability to produce an inflorescence, not from abortion of flower buds (Dielen et al., 2004). Moreover, doublemutants which involve ufallele in combinations with sft, b/or j mutations all develop a single normal flower (Quinet et al., 2006a; Quinet and Kinet, 2007), demonstrating the epistatic interaction of $U F$ respect to the remaining IM genes.

Phenotypes of jointless $(\lambda)$ and macrocalyx $(m c)$ mutants display a reversion of the IM to a vegetative developmental programme (Fig. 2), allowing normal shoot formation and indicating that maintenance of IM identity requires Jand $M C$ genes (Rick and Sawant, 1955; Rick and Butler, 1956; Vrebalov et al., 2002; Szymkowiak and Irish, 2006). Also the identity of IM is lost in the sftmutant after one or two flowers are developed (Fig. 2 ). It then reverts to a vegetative state and the position of the following flower is occupied by a sympodial shoot. Thus, SFT prevents the change of identity of the inflorescence meristem once flowering is initiated (Molinero-Rosales et al., 2004).

Before flower development, floral identity is determined in the IM by the FALSIFLORA gene (Molinero-Rosales et al., 1999). The faallele promotes a strong inflorescence phenotype due to the replacement of flowers by secondary leafy shoots (Fig. 2 and Fig. 3B), as occurs in Antirrhinum floand Arabidopsis Ify mutants. A careful examination of early development of fa inflorescence has shown that it is not the inflorescence meristem, but rather derived vegetative meristems which are unable to acquire floral identity (Allen and Sussex 1996). FA is the orthologue to the Arabidopsis $\angle F Y$ gene, the latter being extensively analysed since it is the major responsible for the transition from inflorescence to floral meristem in the model species (Weigel et al., 1992; Blázquez and Weigel, 2000). The high sequence similarity observed between $F A$ and $\angle F Y$ affecting DNA-binding domains and other regulatory elements should lead to further analyses about the mechanism determining floral meristem identity in tomato.

Mutations of $A N A N T H A(A N)$ and $S$ genes also modify the developmental fate of IM giving rise to highly branched inflorescences composed either by reproductive meristems or normal flowers, respectively (Rick and Butler, 1956; Allen and Sussex, 1996). Such observations indicate the failure of the meristems emerging from the IM to specify floral identity. Recently, Lippmann et al. (2008) have demonstrated that $A N$ encodes an F-box ortholog of the Arabidopsis floral gene UNUSUAL FLORAL ORGANS (UFG) while $S$ gene codes for a transcription factor homologous to WUSCHEL-HOMEOBOX9 (WOX9/) $S T I M P Y$ Y. Functional analyses of these two genes indicated that sympodial architecture of tomato inflorescence is made by the sequential expression of $S$ and $A N$, which in turn promotes the phase transition of a IM to a floral meristem. Double-mutant analyses have shown that $F A$ acts upstream to $A N$, confirming the key function of $F A$ gene in the specification of floral identity.

The leafy phenotype of fa mutant is also achieved by overexpression of $S P$ in wild type tomato and $s p$ mutant plants. Similarly, the reproductive nature of an proliferating meristems is changed and vegetative shoots are also developed when $S P$ is overexpressed. Both results make that the contribution of $S P$ to the control of floral meristem identity can not be discarded. Moreover, expression domains of $S P$ coincide with those of $F A$ being the latter gene, epistatic to $S P$ (Pnueli et al., 1998; Molinero-Rosales et al., 1999). Thus, the mutual negative regulation existing in Arabidopsis between $\angle F Y$ and $T F L 1$ is unlikely to occur between $F A$ and $S P$ in tomato. Most probably, $F A$ could regulate floral identity by both activating $A N$ and decreasing $S P$ activity in the reproductive meristems.

In summary, $B L, J, S F T, M C, U F, A N$ and $S$ genes play important roles in the maintenance of reproductive meristem identity and together with $F A$ and $S P$ are required for other flowering-related processes (Fig. 2), i.e. floral transition ( $F A$, $S F T, B L$ and $U F$ ), sympodial growth of plant ( $S P, S F T$ and $B L$ ), inflorescence architecture $(A N$ and $S$ ) and floral organ development (MC). Therefore, further research should distinguish the main function of these genes from their pleiotropic effects during plant development, as Lifschitz et al. (2006) have recently done for SFT.

\section{Floral organ development}

At maturity, the hermaphrodite and symmetric flower of tomato consists of four whorls each formed from the outermost by 5-6 green sepals, which alternate to a similar number of yellow petals at the second whorl, about 6 stamens displaying anthers forming a cone around the style, and a variable number of fused carpels in the innermost whorl.

Genetic analyses in Arabidopsis and Antirrhinum have led to propose three main gene functions, A, B and C, each including a few number of genes, which acting alone or in combination determine organ identity in the four floral whorls. The so-called ABC model (Coen and Meyerowitz, 1991; Meyerowitz et al., 1991) has been confirmed in several plant species and assumes that mutations affecting A-, B- and C-class genes promote homeotic changes in the floral organs of two consecutive 
whorls. Most of the ABC genes belong to the MADS-box family encoding transcription factors, which are highly conserved among plant species. MADS proteins bind to DNA as multimeric complexes which ultimately control the development of floral organs (see Robles and Pelaz, 2005).

Characterization both of homeotic mutants and transgenic plants where homologous $A B C$ genes have been up- or downregulated seems to confirm the $\mathrm{ABC}$ model in tomato (Table 2 ). The macrocalyx mutation resides in a homologue to the $A P 1$, an Arabidopsis A-function gene (Vrebalov etal., 2002). Expression of $M C$ is detected in sepals, petals and carpels while either mutation or gene silencing of $M C$ causes homeotic conversion from sepals to leaf-like structures (Rick and Butler, 1956; Vrebalov et al., 2002). Both the mutant phenotype and the pattern expression of $M C$ are however more similar to $S Q U A$ MOSA (SQUA), the AP1 orthologue of Antirrhinum.

Several B-class mutants showing partial or complete transformations in the second and third organ whorls have been identified in tomato (Nash et al., 1985; Sawhney, 1992). Among them, stamenless ( $s$ ) and its allelic mutant corollaless (cs) show sepals instead of petals in the second whorl and stamens replaced by carpels in third whorl (Fig. 3D; Gómez et al., 1999). Mutation of $S L$ affects to a B-class gene homologous to DEFICIENS (DEF) in Antirrhinum and APETALA3 (AP3) in Arabidopsis, both involved in the development of petals and stamens. In addition, among the several TOMATO MADS BOX genes (abbreviated as TMor TDR), TM6also shares homology to $A P 3$, yet mapping data reject it as candidate for $S L$ gene (Gómez et al., 1999).

Regarding tomato C-class genes, tomato mutants with homeotic changes in both reproductive organs (whorls 3 and 4) have not been described until now. However, TOMATO AGAMOUS1 (TAG1), a tomato orthologue to the Arabidopsis AGA$\operatorname{MOUS}(A G)$ gene has been isolated. Tomato plants expressing sense and antisense TAG1 transcripts corroborate the role of TAG1 in the specification of stamen and carpel identities (Pnueli et al., 1994a).

Recently, the ABC model has been extended with two new classes of genes. D-class genes control ovule identity and were initially described in Petunia after the functional and molecular analyses of FLORAL BINDING PROTEINT(FBPT) and FBP11 (Angenent et al., 1995). The Arabidopsis D-class gene is SEEDSTICK (STK) which, like FBP7and FBP11, is specifically expressed in ovules (Pinyopich et al., 2003). Furthermore, it has been proven that $A, B$ and $C$ genes require an additional function which cooperates with them in the development of the four floral organs. Such function is carried out by the E-class SEPALLATA (SEP) genes. Strong evidence was found to support the formation of multimeric complex involving $A, B, C$ and SEP proteins, as mechanism which triggers flower development (see Robles and Pelaz, 2005 for references). In tomato, TM5 (Pnueli et al., 1994b) and TM29 (Ampomah-Dwamena et al., 2002) have been described as two SEP-like genes on the basis of their expression pattern and down-regulated phenotypes. These and other tomato genes involved in carpel and ovule development are further described in the next section.

Activity of floral organ identity genes seems to depend on $F A$ gene, as suggested by the inhibition of TM5, TM6 and TAG1 expression in fainflorescences, as well as by the phenotype of weak mutant alleles of $F A$ which allow floral organ development (Kato et al., 2005; R. Lozano, unpublished). Therefore, FA plays in important role in the control of floral meristem identity but it may also induce floral organ identity genes.

\section{More about carpel and ovule development}

Bearing in mind the importance of the carpels as sexual floral organs which protect ovules and allow seed formation, much progress has been made in the identification of genes and protein interactions regulating carpel development. As previously mentioned, $A G$ gene determines the identity of carpel primordia located at the fourth whorl of a developing flower, which also requires the activity of SEPALLATA genes in Arabidopsis (Pelaz et al., 2000). However, carpelloid organs instead of sepals can be developed in the absence of $A G$, as happens in the first whorl of ag ap2flowers, indicating that an additional $A G$-independent pathway can also specify carpel features (Pinyopich et al., 2003). SHATTERPROOF1 (SHP1), SHP2 and SEEDSTICK (STK), members of the same $A G$ clade, have been identified as key genes of this pathway. $A G$ acts redundantly to $S H P$ genes to promote carpel development, while $A G, S H P$ and $S T K$ play redundant roles in the specification of ovule identity (Liljegren et al., 2000; Pinyopich et al., 2003; Favaro et al., 2003). While no protein-protein interactions were observed among $A G, S T K$ and $S H P$ genes, all three interact with $S E P 3$, suggesting that SEP proteins mediate the formation of a protein complex directing ovule and carpel identity (Favaro et al., 2003). Likewise, overexpression and down-regulation of FBPT and FBP11, two STK orthologous genes of Petunia, confirm that an ovule-specific function is carried out by these MADS-box transcription factors, which in

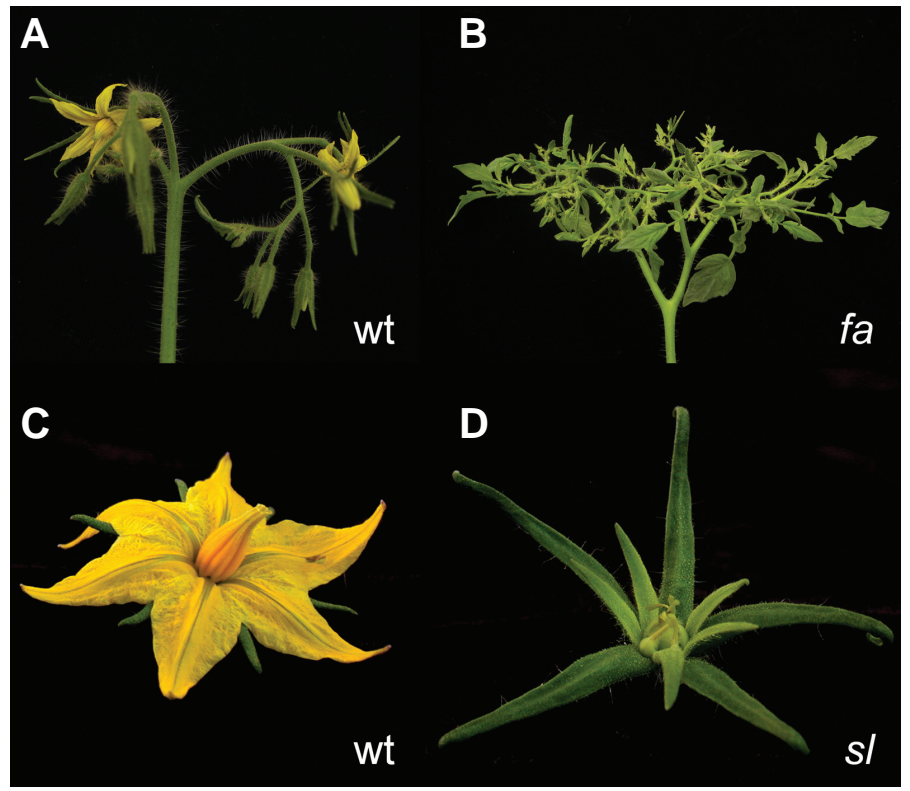

Fig. 3. Tomato mutants affected in floral meristem identity or flower development. Respect to the wild type inflorescence (A), flowers of the falsiflora (fa) mutant are replaced by secondary vegetative shoots (B), demonstrating that FA gene controls floral meristem identity. The development of a normal tomato flower (C) is altered in the stamenless (sl) mutant, which shows homeotic conversion of petals into sepals in whorl 2, and carpels instead of stamens in whorl 3 (D) 
TABLE 2

TOMATO MUTANTS AND GENES IMPLICATED IN FLOWER DEVELOPMENT

\begin{tabular}{|c|c|c|c|c|c|}
\hline \multicolumn{2}{|c|}{ Mutant or gene } & \multirow{2}{*}{$\begin{array}{l}\text { Phenotype } \\
\text { Large sepals, indeterminate inflorescence }\end{array}$} & \multirow{2}{*}{$\begin{array}{l}\text { Gene } \\
\text { LeMADS-MC (MC in text) }\end{array}$} & \multirow{2}{*}{$\begin{array}{l}\text { Reference } \\
\text { Rick and Sawant, } 1955 \\
\text { Verbalov et al., } 2002\end{array}$} & \multirow{2}{*}{$\begin{array}{l}\text { Arabidopsis orthologue } \\
\text { A-class }\end{array}$} \\
\hline A-class & macrocalyx $(m c)$ & & & & \\
\hline \multirow[t]{2}{*}{ B-class } & stamenless (sl) & $\begin{array}{l}\text { Homeotic conversion of petals and stamens into sepals and carpels, } \\
\text { respectively }\end{array}$ & $S L$ & $\begin{array}{l}\text { Nash et al., } 1985 \\
\text { Gomez et al., } 1999\end{array}$ & B-class \\
\hline & TM6 & Silencing of TM6 alters stamen development & TM6 & de Martino et al., 2006 & \\
\hline C-class & TAG1 & $\begin{array}{l}\text { Down-regulation of TAG1 causes homeotic transformations of stamens and } \\
\text { carpels }\end{array}$ & TAG1 & Pnueli et al., 1994a & C-class \\
\hline \multirow[t]{2}{*}{ E-class } & TM5 & Down-regulation alters organ differentiation in the inner three floral whorls & TM5 & Pnueli et al., 1994b & E-class \\
\hline & TM29 & $\begin{array}{l}\text { Down-regulation of } T M 29 \text { affects the maintenance of floral meristem identity } \\
\text { (flowers altered in the inner three whorls) }\end{array}$ & TM29 & Ampomah-Dwamena et al., 2002 & \\
\hline
\end{tabular}

turn are able to interact with SEP -like proteins such as FBP2, FBP5 and FBP9 (Angenent et al., 1995; Ferrario et al., 2003).

Genes homologous to some of those mentioned above as being involved in the control of carpel and ovule development have been also described in tomato (Table 2). SEPALLATA homologues TM5 and TM29 (TAGL2) regulate floral organ identity and fruit development (Pnueli et al., 1994b, AmpomahDwamena et al., 2002). Co-suppression or antisense expression of these tomato SEPgenes result in homeotic alterations in the inner three whorls resembling those observed in petunia transgenic plants lacking activity of FBP2 or FBP5genes. After fertilization TM29 expression is confined to the ovary, in particular to developing seeds and vascular bundles, which would link the post-fertilization process to fruit formation in tomato.

As previously mentioned, TAG1, the tomato AGorthologue, is required for the appropriate development of carpels at the fourth whorl of tomato flower (Pnueli et al., 1994a). Other AGlike MADS-box genes expressed during tomato reproductive development have been isolated (Busi et al., 2003). Nucleotide sequences of TAGL 1 and TAGL11 genes show a high similarity to SHP1 (AGL 1), and STK (AGL11), respectively. Moreover, expression patterns of TAGL1 and TAGL11 are quite similar, being their transcripts detected at the inner integument of the ovules and the carpel walls. These results suggest overlapping functions of the two genes in the specification of ovule identity and in the control of fruit development, as occurs with their homologues SHP1 and STK in Arabidopsis. Accordingly, yeast two-hybrid experiments have revealed dimer formation between TM29 and each of TAG1, TAGL1 and TAGL11. Taken together, these data seem to indicate that the proteins encoded by TM29, TAG1, TAGL11 and TAGL1 play an important role in the regulation of gene expression during early fruit development (ovule, seed and carpel development), functioning together as transcriptional complexes (Busi et al., 2003). Despite the formation of different fruit types (siliques in Arabidopsis, berries in tomato), the molecular pathway involved in fruit development is most likely conserved, as suggested by the presence of genes sharing similarities in their structure and function, as well as comparable expression patterns and interactions.

The development of a flower as a whorled and determinate reproductive structure implies that determinacy of the floral meristem should be achieved once the carpel identity has been acquired by the fourth whorl organ primordia. In Arabidopsis, this process is regulated by the homeodomain encoding genes
WUSCHEL (WUS) and SHOOTMERISTEMLESS (STM) which operate at different meristematic domains. The ceasing of activity in the floral meristem depends on a negative feedback loop involving $W U S, \angle F Y$ and $A G$, in such a way that the first two genes would activate $A G$, which in turn would repress $W U S$ once the flower has completed floral organ development (Lohmann et al., 2001). In petunia, the formation of multimeric complex involving C-, D- and E-class MADS-box transcription factors could be responsible for the repression of TERMINA$T O R$, the WUS homologue in this species (Ferrario et al., 2006). Concerning tomato, down-regulation of TAG1 promotes flower indeterminacy featured by the replacement of carpels at the fourth whorl by ectopic floral-like structures bearing indeterminate floral meristems. Such homeotic changes support a role of TAG1 in the determinacy of floral meristem (Pnueli et al., 1994a).

Molecular isolation of new mutants and orthologous genes affected in the floral meristem size are required in tomato, as well as new insights into the genetic interactions they keep with floral meristem identity genes such as $F A$ and TAG1. They could provide evidence about the conservation of the genetic pathway which regulates floral meristem determinacy in different plant species, as well as genetic and molecular singularities that distinguish the sympodial meristem from the SAM.

\section{Tomato as model system for fruit development}

Upon fertilization of the ovules, the carpels become a complex organ, forming the mature fruit, this ensuring seed dispersal and therefore survival of the plants. Mature fruits can be classified generally as either fleshy or dry, which mainly differ in the mechanism achieved to permit seed dispersal. A senescence program leading to fruit dehiscence is needed before some external agent (e.g. wind, rain, and physical contact) can force seeds to be released from dry fruits. However, fleshy fruits have evolved edible components making them attractive for animals, which facilitate dispersion of the seeds without any other requirements. Tomato plants produce fleshy red fruits as result of a developmental process which includes three phases (Gillaspy et al., 1993). The first phase starts just at anthesis and involves the development of the ovary and the decision to abort or to proceed with fruit development (i.e. fruit set). In the second phase, fruit growth is due primarily to cell division and the embryos begin their development. Finally, cell division ceases at the third phase and fruit growth continues by cell expansion 
until the fruit reaches its final size. Once a fully developed fruit has been formed and seeds are mature, respiration and ethylene synthesis are significantly increased allowing ripening and maturation. As result, biochemical and physiological changes affecting colour, texture, flavour, aroma, nutritional content and susceptibility to opportunistic pathogens are made visible from the onset of ripening. Later, a softening process occurs as part of ethylene-induced gene activities which promote degradation of cell walls in different fruit compartments (Giovannoni, 2004). On the other hand, the sharp increase in respiration rate, which usually occurs in combination with elevated ethylene production at the onset of fruit ripening, are considered specific features of climacteric fruits like tomato. Indeed, such features are absent during ripening of non-climateric fruits such as strawberry, grapes, legumes or citrus.

Taking into account the economic and nutritional importance of the fruits as essential components of human and animal diets, considerable scientific work is required to improve fruit yield and quality. Arabidopsis thaliana has proven to be an exceptional model for gaining insight into the genetic, molecular and hormonal factors which regulate development and dehiscence of fruits. However, significant contributions in the fields of hormonal regulation of ovary growth, physiology of ripening, and genetic control of fruit size and shape have taken tomato as a model system given the developmental features of fleshy fruits (see reviews by Giovannoni, 2004; Tanksley, 2004; Gorguet et al., 2005). Recent discoveries on the regulatory mechanisms of fruit development and ripening have revealed the key role played by certain transcriptional factors, suggesting that some developmental regulators are conserved among plant species. Furthermore, ethylene perception and signalling pathways which control fruit development seem to share a common molecular basis in different species, although alterations in gene expression patterns and gene family composition may account for differences in fruit developmental patterns among species. This review focuses on the early stages of fruit development and ripening. Subsequent stages of fruit maturation is not considered since exhaustive reviews have recently been published on these topics (Giovannoni, 2004, 2007).

\section{Hormonal control of fruit development and partheno- carpy}

Fertilization of the ovules usually triggers development of the ovary into a fruit as pollen germination generates growth stimuli (Gillaspy et al., 1993). Some of the growth factors controlling fruit set by pollen include auxins and gibberellins. Furthermore, auxins and ethylene control early stages of fruit development by inducing the expression of several gene families (Balbi and Lomax, 2003). However, successful development of tomato fruits can also occur in the absence of fertilization, a physiological event called parthenocarpy, which leads to the formation of seedless fruits (Lukyanenko, 1991).

Classic research into plant physiology has suggested that tomato parthenocarpy is related to an imbalance in hormonal control, as revealed by the fruit phenotypes observed after hormone applications or when plants grow under adverse conditions, mainly extreme temperatures (see Gorguet et al., 2005). Parthenocarpic development has also been observed in tomato backgrounds displaying deficiencies in pollen formation and/or anther dehiscence (male sterility) which result in failure of fertilization. The low level of both cytokinins and gibberellins detected in the male-sterile stamenless-2 of tomato suggests that these hormones may alter fertility (Sawhney and Shukla, 1994). Accordingly, anther- and pollen-specific expression of negative regulatory genes of cytokinin- or GA-signalling produce abortion of anther and pollen in transgenic plants of maize, tobacco and Arabidopsis (Huang et al., 2003). These results agree with the functional implications of cytokinins and GAs in the reproductive development of plants. Additionally, jasmonic acid and ethylene have been found to synchronize pollen maturation, anther dehiscence and flower anthesis (see references in Gorguet et al., 2005). Parthenocarpic fruits can be developed in absence of this normal synchronous development of male and female gametophytes, particularly in selfpollinating crops.

Besides the importance of plant hormones during pollination, gibberellins constitute a key factor for setting and development of tomato fruit. GA produced by developing seeds promotes a normal fruit development (García-Martínez et al., 1991). Accordingly, exogenous GA can replace the promoter growth effects of GA-producing seeds, which result in a successful fruit set and parthenocarpy. Together with gibberellins, auxins are also involved in the parthenocarpic development of fruits. Enzyme activities involved in GA biosynthesis are regulated by auxins, which in turn are needed to maintain the level of active GAs (García-Martínez et al., 1997; Ross et al., 2000). Recent evidences have shown that early stages of fruit development in tomato are also dependent on auxin- and ethylenemediated gene expression and that both auxin and ethylene responses are regulated specifically by the Diageotropica(DGT) gene (Balbi and Lomax, 2003). Therefore, it is likely that GA is involved in later stages of fruit and seed development, whereas the remaining hormones regulate early stages of these processes.

The physiological mechanisms underlying parthenocarpic development of the fruits remain largely unknown. Nevertheless, characterization of parthenocarpic tomato mutants has favoured a better understanding of the genetic and molecular basis of this process (Table 3 ). The recessive parthenocarpic (pat) mutant exhibits abnormal flower development, mainly premature ovary growth, reduced number of viable ovules and increased number of pericarp cell layers (Soressi and Salamini, 1975; Mazzucato et al., 1998), the former two being responsible for the impaired fertilization and development of seedless fruits. Parthenocarpy is also induced by an independent recessive mutation pat-2 (Philouze and Maisonneuve, 1978; Nuez et al., 1986), which also produces unfavourable pleiotropic features (i.e. less plant vigour and reduced fruit set and yield) depending on the genetic background. The third genetic source of parthenocarpy is polygenic, with two genes pat-3and pat-4 as the most probable determinants of this trait (Nuez et al., 1986).

It has been suggested that parthenocarpy of pat mutant could be related to a gene with homeotic functions in accordance with the phenotypic similarities observed when TM5 or TM29MADS-box genes are down-regulated (Mazzucato et al., 1998). Nevertheless, it remains unclear whether the parthenocarpy is directly regulated by TM proteins or is caused by 
hormonal changes related to abnormal development of reproductive organs which finally results in unsuccessful fertilization. Interestingly, steady-state levels of expression of TM4 (TDR4), a tomato MADS-box gene homologous to FUL, are highly increased in parthenocarpic ovaries grown under low temperatures (Lozano et al., 1998). Similarly, transcripts of $L e-D E F$, a tomato B-class MADS-box required for petal and stamen development, are significantly accumulated in GA-treated flowers, which give rise to parthenocarpic fruits, while they are completely abolished by paclobutrazol, an inhibitor of GA biosynthesis (authors' unpublished data). These results suggest that GA-mediated expression changes of MADS-box genes could be at the origin of tomato parthenocarpy, whether through regulation of reproductive organ development (stamens and carpels) or changes in GA-signalling or biosynthesis. Additionally, PAT interactions may regulate the ovary-pollen developmental synchrony and hence, fruit formation. Beraldi et al. (2004) has recently mapped the PATgene, which will allow not only the cloning of the gene but also a more detailed analysis of genetic interactions regulating parthenocarpic development of fruits.

Differential expression analyses have found that pat2 and pat3/pat4 alleles enhance GA biosynthesis pathways, the high level of active GAs being responsible for parthenocarpic development of tomato fruits observed in both mutant backgrounds (Fos et al., 2000; Fos et al., 2001). Moreover, seedless fruit development of pat2 requires $\angle A T E R A L S U P P R E S S O R$ activity since parthenocarpy is avoided by the presence of $/ s$ mutant allele (Philouze, 1983). These results agree with the function proposed for $L S$ as a gene regulator of $G A$ sensitivity (Schumacher et al., 1999). Therefore, mechanisms which explain parthenocarpic development in pat2 and pat3/pat4 tomato mutants should include changes in the GA regulation.

Taking as a whole, these results indicate that parthenocarpy is a complex developmental process regulated by genetic, hormonal and environmental factors. Its scientific and agro- nomic interest should promote additional efforts to elucidate the molecular and genetic basis of the mechanisms underlying parthenocarpic fruit development. To this end, tomato is an excellent model system, even more so when current progress in functional genomic studies and the ongoing sequencing project can be exploited.

\section{Tomato genes controlling fruit size and shape}

Among the evolutionary features affected by the domestication are those related to external appearance of fruits. In this context, tomato is an excellent model to study natural variation and gene function since a wide diversity of phenotypes affected in fruit size and shape can nowadays be observed in the cultivated and wild-related tomato germplasm. Genetic mapping approaches have identified a small number of quantitative genes as responsible for the great variation affecting tomato fruit size (Grandillo et al., 1999). Among them, only fw2.2 has been isolated to date and its function is involved in the evolution of small fruited wild tomatoes in to large fruited cultivated tomatoes (see review of Tanksley, 2004). Detailed studies on the expression pattern and the gene dosage effect of this gene have proved that the FW2.2 protein is a negative regulator of cell proliferation in tomato that causes changes in overall fruit size but not in fruit shape (Frary et al., 2000; Liu et al. 2003). In fact, remarkable results on the physical interaction between FW2.2 and $\angle E C K I I \beta 1$, the regulatory subunit of casein kinase II, have been published (Cong and Tanksley, 2006). Nevertheless, essential questions remain to be determined, mainly how this novel gene function has arisen in the plant kingdom and how it has evolved to interact with the well-known component of the cell cycle signaling pathway. Together with the control exercised by the cell cycle, the fruit size also depends on the number of carpels which are determined during early development of tomato fruit and hence, the number of locules forming the mature fruit. Two independent mutations, locule-number

TABLE 3

TOMATO MUTANTS AND GENES ISOLATED TO DATE AS INVOLVED IN FRUIT DEVELOPMENT AND RIPENING

\begin{tabular}{|c|c|c|c|c|}
\hline Mutant or gene & Phenotype & Isolated Gene & Reference & $\begin{array}{l}\text { Arabidopsis orthologue } \\
\text { or encoded protein }\end{array}$ \\
\hline pat & Parthenocarpic fruit, homeotic alteration of reproductive floral organs & & $\begin{array}{l}\text { Soressi and Salamini, } 1975 \\
\text { Mazzucato et al., } 1998\end{array}$ & \\
\hline pat-2 & Parthenocarpic fruit (altered GA metabolism) & & $\begin{array}{l}\text { Phylouze and Maisonneuve, } 1978 \\
\text { Fos et al., } 2000\end{array}$ & \\
\hline pat-3/pat-4 & Parthenocarpic fruit (altered GA metabolism) & & $\begin{array}{l}\text { Nuez et al., } 1986 \\
\text { Fos et al., } 2001\end{array}$ & \\
\hline TM29 & Parthenocarpic fruit & TM29 & Ampomah-Dwamena et al., 2002 & SEPALLATA \\
\hline TDR4 & Gene silencing makes a fruit unable to complete ripening and alters cell wall structure & TDR4 & $\begin{array}{l}\text { Seymour et al., } 2002 \\
\text { Eriksson et al., } 2004 \\
\text { Angosto et al. (unpublished) }\end{array}$ & FRUITFULL \\
\hline fw2.2 & Quantitative variation of fruit size & Fw2.2 & $\begin{array}{l}\text { Frary et al., } 2000 \\
\text { Cong et al., } 2002\end{array}$ & Negative regulator of cell division \\
\hline fasciated & Higher number of carpels/locules in the fruit & FAS & Cong et al., 2008 & YABBY-like transcription factor \\
\hline ovate & Pear-shape or elongated fruit & OVATE & Liu et al., 2002 & New class of nuclear-localized proteins \\
\hline sun & Quantitative fruit size variation & SUN & $\begin{array}{l}\text { Xiao et al., } 2008 \\
\text { Jiang et al., } 2009\end{array}$ & IQ67-domain family \\
\hline nor & Non-ripening fruits & $N A C$ & $\begin{array}{l}\text { Tigchelaar et al., } 1978 \\
\text { Giovannoni et al., } 2004\end{array}$ & NAC domain transcription factor \\
\hline Rin & Non-ripening fruits & $\begin{array}{l}\text { LeMADS-RIN } \\
\text { (RIN in text) }\end{array}$ & $\begin{array}{l}\text { Dostal et al., } 1974 \\
\text { Vrebalov et al., } 2002\end{array}$ & SEPALLATA-like \\
\hline Cnr & Unripe fruit, loss of cell-to-cell adhesion & $\begin{array}{l}\text { LeSPB-CNR } \\
\text { (CNR in text) }\end{array}$ & $\begin{array}{l}\text { Thompson et al., } 1999 \\
\text { Manning et al., } 2006\end{array}$ & $S B L 3$ \\
\hline
\end{tabular}




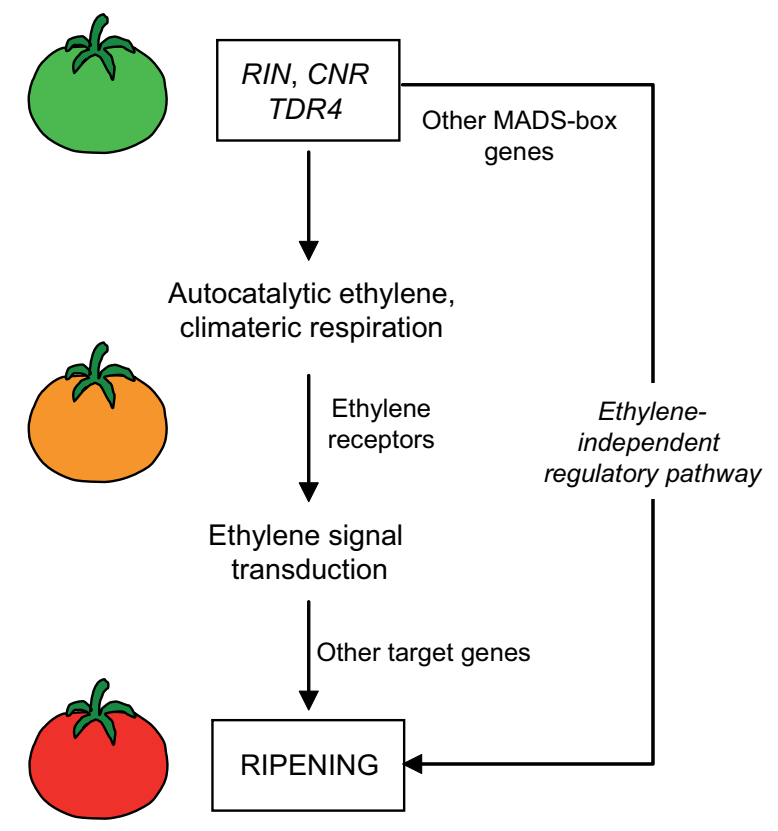

Fig. 4. Genetic regulation of tomato ripening. Transcription factors encoded by RIN and CNR genes are involved in an ethylene-mediated control of fruit ripening and also participate in an ethylene-independent pathway. Presumably, TDR4 gene is also involved in this mechanism of ripening control, while other regulatory and target genes remain to be characterized. Ethylene receptor proteins involved in the ethylene signal transduction promote a cascade of gene activation allowing the ripening of tomato fruits (adapted from Giovannoni, 2007).

and fasciated (fas), identified the quantitative loci involved in this feature, the latter having a greater effect (Barrero and Tanksley, 2004). Positional cloning of the FASCIATED gene has revealed that it encodes a YABBY-like transcription factor and that the high locule-number-phenotype of modern tomato cultivars is caused by downregulation of this gene during floral development. An insertion in the first intron is likely to be responsible for this regulatory change (Cong et al., 2008). Comparative sequencing of either fw2.2 or fas alleles, has led to two important conclusions: i) fruit size variation is modulated not by changes in the coding sequence of either the 22-kD FW2.2 or the FAS protein but due to differences in the transcriptional activity during flower development associated to changes in the 5 ' regulatory sequence of the corresponding genes (Cong et al., 2002; Cong et al., 2008), and ii) fw2.2 and fas represent early and late steps, respectively, in the fruit size variation accounted for domestication (Tanksley, 2004; Cong et al., 2008).

Genetic pathways which regulate fruit size and shape of tomato seem to share some components as the organ-determining genes fasciated and locule-number, which affect both external features (Tanksley, 2004). Nevertheless, two major genes involved in fruit shape variation (described as the ratio of fruit height over width) with little or no effects on fruit size, have recently been isolated. OVATE was cloned and found to code a new class of hydrophyllic proteins with a putative nuclear localization signal (Liu et al., 2002). Recessive effects of the single ovate mutation promote an elongated or pear-shaped fruit as a result of a premature stop codon in the second exon which generates a truncated protein. This locus is early expressed during flower development although its transcripts can be detected two weeks after anthesis coinciding with the first step of fruit formation. However, the second major locus, the SUN gene, affects fruit shape after anthesis (Xiao et al., 2008). Besides, whereas ovate mutation usually results in an asymmetric elongation of fruits, sun mutant plants yield elongated and oval shaped tomatoes that maintain the bilateral symmetry. The sun phenotype was caused by an unusual 24.7-kilobase interchromosomal gene duplication event mediated by retrotransposon Rider. When situated in a new genomic context, SUN is expressed at increased levels regarding the ancestral copy, most likely driven by regulatory control of the defensingene (DEFL 1), which culminates in an elongated fruit shape (Xiao et al., 2008; Jiang et al., 2009). The SUN locus encodes an IQD12 protein belonging to the IQ67 domaincontaining family and its transcription levels are responsible for the variation of tomato fruit shape (Xiao et al., 2008). Together with these two loci, quantitative mapping studies (Grandillo et al., 1999; Ku et al., 2000; Brewer et al., 2007; Gonzalo and Van der Knaap, 2008) have shown that several QTLs, emphasizing the well studied fruit shape 8.1QTL (fs8.1), are also associated to fruit shape variation. Like fasciated and ovate, fs 8.1 functions mostly during early floral development and has little if any activity after anthesis (Ku et al., 2000). Presumably, gene interactions controlling shape and size of tomato fruit will soon be elucidated and with this, the molecular mechanisms underlaying morphological variation of tomato fruit.

\section{Genetic regulation of fruit ripening}

The onset of ripening in tomato occurs after the cell expansion stage in the developing ovary has finished and seeds are mature. Physiological studies have concluded that ripening process is characterized by a higher respiration and the autocatalytic synthesis of ethylene (Lelievre et al., 1997), the latter being a major determinant of the phenotypic changes affecting colour, texture, aroma and pathogen susceptibility of fruits. Given the importance of ethylene, most of the research into fruit development has focused on the ethylene-dependent regulatory genes (Cara and Giovannoni, 2008), mainly those involved in the perception and biosynthesis of this hormone (Fig. 4). However, here we review the genes acting upstream or in parallel to the ethylene-regulated pathway. Their functional roles should help us to understand the genetic framework, hormonal interactions and molecular pathways which together regulate fruit development in tomato.

Tomato TDR4 gene was one of the first reported to be involved in tomato fruit development (Seymour et al., 2002; Busi et al., 2003). TDR4 encodes a SQUAMOSA MADS-box transcription factor and is expressed early in the floral meristem, while later at anthesis, TDR4 transcripts are accumulated in ovules and carpel walls. Upon fruit set and during cell division stage, expression of TDR4 is observed in several tissues of the growing ovary. Although the expression level of this gene seems to be low during fruit development, a significant increase is detected at the onset of ripening. Taken into account the expression pattern and the high sequence homol- 
ogy, Seymour et al. (2002) proposed TDR4 as an orthologue of FRUITFULL (FUL) gene of Arabidopsis, the latter being a negative regulator of $S H P$ genes during fruit dehiscence (Ferrándiz et al., 2000). Moreover, the putative formation of TDR4-TM29 and TDR4-TAG1 dimers described by Busi et al. (2003) would support that TDR4 may participate as a linking factor between flower and fruit development. In fact, tomato MADS-box genes involved in fruit development are also expressed in different stages of floral development, suggesting that fruit and seed development may be considered as a continuation of the floral development program. TM29, TAGL1 and $T A G L 11$ are induced immediately after anthesis in the ovary (Busi et al., 2003), making them candidates to participate in the signalling pathways which trigger fruit development once successful fertilization has taken place (Fig. 4). Nevertheless, other functional similarities between FUL and TDR4, in particular the existence of genetic interactions of TDR4 with MADSbox genes involved in fruit ripening, similar to those described between FUL and SHPgenes, remain to be investigated.

Some of the first evidences supporting an upstream transcriptional control of fruit development came from the characterization of tomato mutants altered in the ripening process (reviewed by Giovannoni, 2004, 2007). Among them, ripeninginhibitor (rin), non-ripening (nor) and Colorless non-ripening $(\mathrm{Cnn})$ mutants all produce fruits which are unable to ripen (Table 3 ) even after being treated with exogenous ethylene. Also, the lack of ethylene production and increased climacteric respiration are features shared by these mutants (Vrebalov et al., 2002; Giovannoni et al., 2004; Manning et al., 2006). Such results indicate that the affected genes $R I N$, NOR and CNR promote fruit ripening by a regulatory pathway acting upstream to the ethylene biosynthesis and signalling. Additionally, these genes should also participate in an ethylene-independent pathway (Fig. 4) as indicated by the expression changes of ethylene-regulated genes induced by this hormone in rin, nor and Cnrfruits (see Giovannoni, 2007). RINis a MADS-box gene of the $S E P$-clade whose mutant recessive allele is caused by a partial deletion which results in a chimeric transcript (Vrebalov et al., 2002). Cnr mutation promotes a dominant epigenetic alteration in the promoter of a SBP-box (SQUAMOSA promoter binding protein) gene (Manning et al., 2006), while the less analysed NOR gene encodes a NAC domain transcription factor (Giovannoni et al., 2004).

Genetic interactions among ripening regulators and other fruit developmental genes are being elucidated, but hierarchic relationships among the encoded proteins remains unknown. In agreement with the increased level of TDR4 transcripts detected when tomato fruits start to ripen (Seymour et al., 2002; Eriksson et al., 2004), TDR4 expression is reduced in the nonripening mutants rin, norand Cnr. Furthermore, TDR4loss-offunction produces a slight increase in cell wall stiffness of fruits consistent with a TDR4s role in regulating cell wall structure (Eriksson et al., 2004). In agreement, RNAi-mediated inactivation of TDR4 makes tomato fruits unable to complete ripening (Angosto et al., unpublished data). Therefore, TDR4 gene has been proposed as a suitable candidate to regulate the ripening process, together RIN, NOR and CNR(Eriksson et al., 2004). Even more, the formation of putative dimers between TDR4 and other MADS-box proteins (TM29 and TAG1) detected by yeast two-hybrid analysis could be extended to RIN, as a hypothetical mechanism of ripening control similar to that operating for the specification of floral organ identity (Giovannoni, 2004). In the same way, putative interactions between CNR and TDR4 proteins have been proposed by Manning et al. (2006) based on the ability of SBP-box gene products to interact with a sequence motif of the SQUAMOSA promoter.

The expression of $R / N$ and $N O R$ appear unaffected in $\mathrm{Cnr}$ mutant fruits, suggesting that they either participate in a separate pathway from $C N R$ or act upstream in the ripening cascade (Eriksson et al., 2004; Giovannoni, 2007). Additional work is needed to determine genetic and molecular relationships among ripening genes and to identify their targets.

\section{Future prospects}

Significant contributions to the developmental genetics of tomato have been made during the last two decades. Genetic analysis of tomato mutants and candidate gene approaches are providing excellent tools to isolate key genes involved in vegetative and reproductive development. The cloning and functional analysis of tomato homologous genes have revealed that many developmental processes are controlled by genes and proteins which are highly conserved among plant species (e.g. Arabidopsis, Anthirrinum, petunia). However, specific features of tomato fruit seem to require novel gene functions, which have begun to be identified with the isolation of transcription factors involved in fruit development and ripening. Recent genomic research indicates that new tomato regulatory genes should be characterized as regulators of the reproductive development in this crop species. In fact, new mutations affecting floral transition and fruit development have been isolated from an in silico screening of a saturated tomato library (Menda et al., 2004) and by insertional mutagenesis (R. Lozano, unpublished data). In addition, EST and microarray analyses have allowed the identification of thirteen additional MADS-box genes and more than fifteen putative transcription factors which are expressed in ripening fruits (Giovannoni, 2007). In coming years, major challenges will focus on isolating new developmental genes and bridging the gap between these genes and their functions. Genomic and sequencing initiatives currently in progress can be expected to unveil the genetic pathways and molecular interactions among transcription factors which regulate when and how flowers and fruits are formed. Taken as a whole, these results would favour novel strategies to improve the productivity and fruit quality of tomato.

\section{Acknowledgements}

We thank Cristina Ferrándiz and Marcos Egea-Cortines for their comments and critical reading of the manuscript. This work has been supported by grants B102005-09038 and AGL2006-15290-C03-02 from the Ministerio de Educación y Ciencia (Spain).

\section{References}

ALLEN. K.D. and SUSSEX, I.M. (1996). Falsiflora and anantha control early stages of floral meristem development in tomato (Lycopersicon esculentum Mill.). Planta 200: 254-264.

AMPOMAH-DWAMENA, C., MORRIS, B.A., SUTHERLAND, P., VEIT, B. and YAO, J.L. (2002). Down-regulation of TM29, a tomato SEPALLATA homolog, 
causes parthenocarpic fruit development and floral reversion. Plant Physio/ogy 130: 605 - 617.

ANGENENT, G.C., FRANKEN, J., BUSSCHER, M., VAN DIJKEN, A., VAN WENT, J.L., DONS, H.J. and VAN TUNEN, A.J. (1995). A novel class of MADS box genes is involved in ovule development in petunia. Plant Cel/7: 1569-1582.

ARUMUGANATHAN, K. and EARLE, E. (1991). Nuclear DNA content of some important plant species. Plant Mol. Biol. Rep. 9: 208-218.

ATHERTON, J.G. and HARRIS, G.P. (1986). Flowering. In The Tomato CropA Scientific Basis for Improvement (Eds. J.G. Atherton and J. Rudich). Chapman and Hall, London. pp. 167-200.

BALBI, V. and LOMAX, T.L. (2003). Regulation of early tomato fruit development by the Diageotropica gene. Plant Physiology 131: 186-197.

BARRERO, L.S. and TANKSLEY, S.D. (2004). Evaluating the genetic basis of multiple-locule fruit in a broad cross section of tomato cultivars. Theor. Appl. Genet. 109: 669-679.

BERALDI, D., PICARELLA, M.E., SORESSI, G.P. and MAZZUCATO, A. (2004). Fine mapping of the parthenocarpic fruit (pat) mutation in tomato. Theor. Appl. Genet. 108: 209-216.

BLÁZQUEZ, M.A. and WEIGEL, D. (2000). Integration of floral inductive signals in Arabidopsis. Nature 404: 889-892.

BREWER, M. T., MOYSEENKO, J. B., MONFORTE, A. J. and VAN DER KNAAP E. (2007). Morphological variation in tomato: a comprehensive study of quantitative trait loci controlling fruit shape and development. J. Exp. Bot.58: 1339-1349.

BUSI, M.V., BustamANTE, C., D’ANGELO, C., HIDALGO-CUEVAS, M., BOGGIO, S., VALLE, E.M. and ZABALETA, E. (2003). MADS-box genes expressed during tomato seed and fruit development. Plant Mol. Biol. 52: 801-815.

CARA, B. and GIOVANNONI, J.J. (2008). Molecular biology of ethylene during tomato fruit development and maturation. Plant Sci. 175: 106-113.

CHETELAT, R.T. (2005). Revised list of miscellaneous stocks. Tomato Genetics Cooperative Reports 55: 48-69.

COEN, E.S. and MEYEROWITZ, E. (1991). The war of the whorls. Genetic interactions controlling flower development. Nature 353: 31-37.

CONG, B., LIU, J. and TANKSLEY, S.D. (2002). Natural alleles of a tomato QTL modulate fruit size through heterochronic regulatory mutations. Proc. Nat/. Acad. Sci. USA 99: 13606-13611.

CONG, B. and TANKSLEY S.D. (2006). FW2.2 and cell cycle control in developing tomato fruit: a possible example of gene co-option in the evolution of a novel organ. Plant Molecular Biology 62: 867-880.

CONG, B., BARRERO, L.S. and TANKSLEY, S.D. (2008). Regulatory change in YABBY-like transcription factor led to evolution of extreme fruit size during tomato domestication. Nature Genetics 40: 800-804

DE MARTINO, G., PAN, I., EMMANUEL, E., LEVY, A. and IRISH, V.F. (2006). Functional analyses of two tomato APETALA3 genes demonstrate diversification in their roles in regulating floral development. Plant Cel/18: 1833-1845.

DIELEN, V., MARC, D. and KINET, J.M. (1998). Flowering in the unifloramutant of tomato (Lycopersicon esculentum Mill.): description of the reproductive structure and manipulation of flowering time. Plant Growth Regulation 25: 149-157.

DIELEN, V., QUINET, M., CHAO, J., BATOKO, H., HAVELANGE, A. and KINET J.M. (2004). UNIFLORA, a pivotal gene that regulates floral transition and meristem identity in tomato ( $\angle$ ycopersicon esculentum). New Phytologist 161: 393-400.

DOSTAL, H.C., MCGLASSON, E.C. and TIGCHELAAR, E.C. (1974). Ripening mutants- A tool to study fruit ripening. Plant Physiology 53: S-61.

ELLUL, P., ANGOSTO, T., GARCIA-SORGO, B., GARCIA-HURTADO, N., MARTIN-TRILLO, M., SALINAS, M., MORENO, V., LOZANO, R. and MARTINEZ ZAPATER JM. (2004). Expression of Arabidopsis APETALA1 in tomato reduces its vegetative cycle without affecting plant production. Molecular Breeding 13: 155-163.

EMMANUEL, E. and LEVY, A.A. (2002). Tomato mutants as tools for functional genomics. Curr. Op. Plant Biol. 5: 112-117.

ERIKSSON, E.M., BOVY, A., MANNING, K., HARRISON, L., ANDREWS, J., DE
SILVA, J., TUCKER, G.A. and SEYMOUR, G.B. (2004). Effect of the colorless non-ripening mutation on cell wall biochemistry and gene expression during tomato fruit development and ripening. Plant Physiology 136: 4184-4197.

FAVARO, R., PINYOPICH, A., BATTAGLIA, R., KOOIKER, M., BORGHI, L., DITTA, G., YANOFSKY, M.F., KATER, M.M. and COLOMBO, L. (2003). MADS-box protein complexes control carpel and ovule development in Arabidopsis. Plant Cel/15: 2603-2611.

FEHLEISEN, S. (1967). Uniflora and conjunctiflora: Two new mutants in tomato. Tomato Genetics Cooperative Reports 17: 26

FERRANDIZ, C., LILJEGREN, S.J. and YANOFSKY, M.F. (2000). Negative regulation of the SHATTERPROOFgenes by FRUITFULL during Arabidopsis fruit development. Science 289: 436-438.

FERRARIO, S., IMMINK, R.G.H., SHCHENNIKOVA, A., BUSSCHER-LANGE, J. and ANGENENT, G.C. (2003). The MADS box gene FBP2 is required for SEPALLATA function in petunia. Plant Ce//15: 914-925

FERRARIO, S., SHCHENNIKOVA, A.V., FRANKEN, J., IMMINK, R.G.H. and ANGENENT, G.C. (2006). Control of floral meristem determinacy in petunia by MADS-box transcription factor." Plant Physiology 140: 890-898.

FOS, M., NUEZ, F. and GARCIA-MARTINEZ, J.L. (2000). The gene pat-2, which induces natural parthenocarpy, alters the gibberellin content in unpollinated tomato ovaries. Plant Physiology 122: 471-480.

FOS, M., PROANO, K., NUEZ, F. and GARCIA-MARTINEZ, J.L. (2001). Role of gibberellins in parthenocarpic fruit development induced by the genetic system pat-3/pat-4 in tomato. Physiologia Plantarum 111: 545-550.

FRARY, A., NESBITT, T.C., GRANDILLO, S., VAN DER KNAAP, E., CONG, B. LIU, J., MELLER, J., ELBER, R., ALPERT, K.B. and TANKSLEY, S.D. (2000). fw2.2. a quantitative trait locus key to the evolution of tomato fruit size. Science 289: 85-88.

GARCÍA-MARTÍNEZ, J.L., LÓPEZ-DIAZ, I., SÁNCHEZ-BELTRÁN, M.J., PHILLIPS, A.L., WARD, D.A., GASKIN, P. and HEDDEN, P. (1997). Isolation and transcript analysis of gibberellin 20-oxidase genes in pea and bean in relation to fruit development. Plant Molecular Biology 33: 1073-1084.

GARCÍA-MARTÍNEZ, J.L., MARTÍ, M., SABATER, T., MALDONADO, A. and VERCHER, Y. (1991). Development of fertilized ovules and their role in the growth of the pea pod. Physiologia Platarum 83: 411-416.

GILIBERTO, G. PERROTTA, G., PALLARA, P., WELLER, J.L., FRASER, P.D., BRAMLEY, P.M., FIORE, A., TAVAZZA, M. and GIULIANO, G. (2005) Manipulation of the blue light photoreceptor Cryptochrome 2 in tomato affects vegetative development, flowering time, and fruit antioxidant content. Plant Physiology 137: 199-208.

GILLASPY, G., BEN-DAVID, H. and GRUISSEM, W. (1993). Fruits: A developmental perspective. Plant Cel/5: 1439-1451.

GIOVANNONI, J.J. (2004). Genetic regulation of fruit development and ripening Plant Cel/16: S170-S180.

GIOVANNONI, J.J. (2007). Fruit ripening mutants yield insights into ripening control. Curr. Op. Plant Biol. 10: 283-289.

GIOVANNONI, J.J., TANKSLEY, S.D., VREBALOV, J. and NOENSIE, E. (2004) NORgene for use in manipulation of fruit quality and ethylene response. US Patent No. 5, 234, 834-issued 13 July 2004.

GÓMEZ, P., JAMILENA, M., CAPEL, J., ZURITA, S., ANGOSTO, T. and LOZANO, R. (1999). Stamenless, a tomato mutant with homeotic conversions in petals and stamens. Planta 209: 172-179.

GONZALO, M. J. AND VAN DER KNAAP, E. (2008). A comparative analysis into the genetic bases of morphology in tomato varieties exhibiting elongated fruit shape. Theor. Appl. Genet. 116: 647-656.

GORGUET, B., VAN HEUSDEN, A.W. and LINDHOUT, P. (2005). Parthenocarpic fruit development in tomato. Plant Biology: 131-139.

GRANDILLO, S., KU, H.M. and TANKSLEY, S.D. (1999). Identifying the loci responsible for natural variation in fruit size and shape in tomato. Theor. Appl. Genet. 99: 978-987.

GREB, T., CLARENZ, O., SCHÄFER, E., MÜLLER, D., HERRERO, R., SCHMITZ, G. and THERES, K. (2003). Molecular analysis of the LATERAL SUPPRES SORgene in Arabidopsis reveals a conserved control mechanism for axillary meristem formation. Genes and Development 17: 1175-1187.

HUANG, S., CERNY, R.E., QI, Y., BHAT, D., AYDT, C.M., HANSON, D.D., MALLOY, K.P. and NESS, L.A. (2003).Transgenic studies on the involvement 
of cytokinin and gibberellin in male development. Plant Physiology 131:12701282.

IMMINK, R.G.H., HANNAPEL, D.J., FERRARIO, S., BUSSCHER, M., FRANKEN, J., LOOKEREN CAMPAGNE, M.M. and ANGENENT, G.C. (1999). A Petunia MADS box gene involved in the transition from vegetative to reproductive development. Development 126: 5117-5126.

JIANG, N., GAO, D., XIAO, H., AND VAN DER KNAAP, E. (2009). Genome organization of the tomato sun locus and characterization of the unusual retrotransposon Rider. The Plant Journal. Doi: 10.1111/j.1365313X.2009.03946.X

JIMÉNEZ-GOMEZ, J.M., ALONSO-BLANCO, C., BORJA, A., ANASTASIO, G., ANGOSTO, T., LOZANO, R. and MARTINEZ-ZAPATER, J.M. (2007). A quantitative genetic analysis of flowering time in tomato. Genome 50: 303315.

KATO, K., OHTA, K., SOMATA, Y., ARAKI, T., KANAHAMA, K. and KANAYAMA, Y. (2005). Morphological and molecular analyses of the tomato floral mutant leafy inflorescence, a new allele of Äfalsiflora. Plant Sci. 169: 131-138.

KERR, E.A. (1982). Single flower truss 'sft' appears to be on chromosome 3. Tomato Genetics Cooperative Reports 32: 31.

KINET, J.M. and PEET, M.M. (1997). Tomato. In The Physiology of Vegetable Crops (Ed. H.C. Wien). Wallingford: CAB International. pp. 207-258.

KOORNNEEF, M.K., BESMA, T.D.G., HANHART, C.J., VAN DER VEEN, J.H. and ZEEVAART, J.A.D. (1990). The isolation and characterization of gibberellin-deficient mutants in tomato. Theor. Appl. Genet. 80: 852-857.

KU, H., GRANDILLO, S. AND TANKSLEY, S. D. (2000). fs8. 1, a major QTL, sets the pattern of tomato carpel shape well before anthesis. Theor. Appl. Genet. $101: 873-878$

LELIEVRE, J.M., LATCHE, A., JONES, B., BOUZAYEN, M. and PECH, J.C. (1997). Ethylene and fruit ripening. Physiol. Plant. 101: 727.

LIFSCHITZ, E. and ESHED, Y. (2006). Universal florigenic triggered by FT homologues regulate growth and flowering cycles in perennial day-neutral tomato. J. Exp. Bot. 57: 3405-3414.

LIFSCHITZ, E., EVIATAR, T., ROZMAN, A., SHALIT, A., GOLDSHMIDT, A. AMSELLEM, Z., ALVAREZ, J.P. and ESHED, Y. (2006). The tomato FT ortholog triggers systemic signals that regulate growth and flowering and substitute for diverse environmental stimuli. Proc. Natl. Acad. Sci. USA 103: 6398-6403.

LILJEGREN, S.J., DITTA, G.S., ESHED, Y., SAVIDGE, B., BOWMAN, J.L. and YANOFSKY, M.F. (2000). SHATTERPROOFMADS-box genes control seed dispersal in Arabidopsis. Nature 404: 766-770.

LIPPMAN, Z. B., COHEN, O., ALVAREZ, J.P., ABU-ABIED, M., PEKKER, I., PARAN, I., ESHED, Y., ZAMIR, D. (2008). The making of a compound inflorescence in tomato and related nightshades. PLOS Biology 6(11): e288.

LIU, J., CONG, B. and TANKSLEY, S.D. (2003). Generation and analysis of an artificial gene dosage series in tomato to study the mechanisms by which the cloned quantitative trait locus fw2.2 controls fruit size. Plant Physiol. 132: 292-299.

LIU, J., VAN ECK, J., CONG, B. AND TANKSLEY, S. D. (2002). A new class of regulatory genes underlying the cause of pear-shaped tomato fruit. PNAS. 99: 13302-13306.

LOHMANN, J.U., HONG, R.L., HOBE, M., BUSCH, M.A., PARCY, F., SIMON, R. and WEIGEL, D. (2001). A molecular link between stem cell regulation and floral patterning in Arabidopsis. Cel/ 105: 793-803.

LOZANO, R., ANGOSTO, T., GOMEZ, P., PAYAN, C., CAPEL, J., HUIJSER, P., SALINAS; J. and MARTINEZ-ZAPATER, J.M. (1998) Tomato flower abnormalities induced by low temperatures are associated with changes of expression of MADS-box genes. Plant Physiology 117: 91-100.

LUKYANENKO, A.N. (1991). Parthenocarpy in tomato. In Genetic Improvement of Tomato, Monographs on Theoretical and Applied Genetics 14. (Ed. G Kalloo). Springer-Verlag, Berlin. pp. 167-178.

MALAYER, J.C. and GUARD, A.T. (1964). A comparative developmental study of the mutant side-shootless and normal tomato plants. Am. J. Bot.51:140143.

MANNING, K., TOR, M., POOLE, M., HONG, Y., THOMPSON, A.J., KING, G.J., GIOVANNONI, J.J. and SEYMOUR, G.B. (2006). A naturally occurring epigenetic mutation in a gene encoding an SBP-box transcription factor inhibits tomato fruit ripening. Nature Genet. 38: 948-952.

MAO, L., BEGUM, D., CHUANG, H.W., BUDIMAN, M,A,, SYMKOWIAK, E,J., IRISH, E.E. and WING, R.A. (2000). JOINTLESS is a MADS-box gene controlling tomato flower abscission zone development. Nature 206: 910913.

MAZZUCATO, A., TADDEI, A.R. and SORESSI, G.P. (1998). The parthenocarpic fruit (pat) mutant of tomato (Lycopersicon esculentum Mill.) sets seedless fruits and has aberrant anther and ovule development. Development 125: 107.

MENDA, N., SEMEL, Y., PELED, D., ESHED, Y. and ZAMIR, D. (2004). In silico screening of a saturated mutation library of tomato. Plant Journa/38: 861872.

MEYEROWITZ, E.M., BOWMAN, J.L., BROCKMAN, L.L., DREWS, G.N., JACK, T., SIEBURTH, L.E. and WEIGEL, D. (1991). A genetic and molecular model for flower development in Arabidopsis thaliana. Development S1: 157-167.

MOLINERO-ROSALES, N., JAMILENA, M., ZURITA, S., GOMEZ, P., CAPEL, J. and LOZANO, R. (1999). FALSIFLORA, the tomato orthologue of FLORICAULA and $L E A F Y$, controls flowering time and floral meristem identity. Plant Journa/20: 685-693.

MOLINERO-ROSALES, N., LATORRE, A., JAMILENA, M. and LOZANO R. (2004). SINGLE FLOWER TRUSS regulates the transition and maintenance of flowering in tomato. Planta 218: 427-434.

NASH, A.F., GARDNER, R.G. and HENDERSON, W.R. (1985). Evaluation of allelism and seed set of eight stamenless tomato mutants. HortScience 20: 440-442.

NUEZ, F., COSTA, J. and CUARTERO, J. (1986). Genetics of the parthenocarpy for tomato varieties "Sub-Artic Plenty", "75/59" and "Severianin". Zeitschrift für Pflanzebzüchtung 96: 200-206.

PELAZ, S., DITTA, G.S., BAUMANN, E., WISMAN, E. and YANOFSKY, M.F. (2000). B and C floral organ identity functions require SEPALLATA MADSbox genes. Nature 405: 200-203.

PERALTA, I.E., KNAPP, S.K. and SPOONER, D.M. (2005). New species of wild tomatoes (Solanum section Lycopersicon: Solanaceae) from Northern Peru. Systematic Botany 30: 424-434.

PHILOUZE, J. (1983). Epistatic relations between /s and pat-2. Tomato Genetics Cooperative Reports 33: 9-12.

PHILOUZE, J. and MAISONNEUVE, B. (1978). Heredity of the natural ability to set parthenocarpic fruits in the Soviet variety Severianin. Tomato Genetics Cooperative Reports 28: 12-13.

PINYOPICH, A., DITTA, G.S., SAVIDGE, B., LILJEGREN, S.J., BAUMANN, E., WISMAN, E. and YANOFSKY, M.F. (2003). Assessing the redundancy MADS-box genes during carpel and ovule development. Nature 424: 85-88.

PNUELI, L., CARMEL-GOREN, L., HAREVEN, D., GUTFINGER, T., ALVAREZ, J., GANAL, M., ZAMIR, D. and LIFSCHITZ, E. (1998). The SELF PRUNING gene of tomato regulates vegetative to reproductive switching of sympodial meristems and is the ortholog of CEN and TFL1. Development 125: 19791989

PNUELI, L., HAREVEN, D., BRODAY, L., HURWITZ, C. and LIFSCHITZ, E. (1994b). The TM5MADS box gene mediates organ differentiation in the three inner whorls of tomato flowers. Plant Cel/6: 175-186.

PNUELI, L., HAREVEN, D., ROUNSLEY, S.D., YANOFSKY, M.F. and LIFSCHITZ, E. (1994a). Isolation of the tomato AGAMOUSgene TAG1 and analysis of its homeotic role in transgenic plants. Plant Cel/ 6: 163-173.

QUINET, M. and KINET, J.M. (2007). Transition to flowering and morphogenesis of reproductive structures in tomato. Int. J. Plant Dev. Biol. 1: 64-74.

QUINET, M., DIELEN, V., BATOKO, H., BOUTRY, M., HAVELANGE, A. and KINET J.M. (2006a). Genetic interactions in the control of flowering time and reproductive structure development in tomato (Solanum lycopersicum). New Phytologist 170: 701-710.

QUINET, M., DUBOIS, C., GOFFIN, M.C., CHAO, J., DIELEN, V., BATOKO, H. BOUTRY, M. and KINET J.M. (2006b) Characterization of tomato (Solanum Iycopersicum L.) mutants affected in their flowering time and in the morphogenesis of their reproductive structure. J. Exp. Bot. 57: 1381-1390.

REEVES, P.H. and COUPLAND, G. (2001). Analysis of flowering time control in Arabidopsis by comparison of double and triple mutants. Plant Physiology 126: $1085-1091$. 
RICK, C.M. (1978). The tomato. Science 239: 66-76.

RICK, C.M. and BUTLER, L. (1956). Cytogenetics of tomato. Advanced Genetics 8: 847-857.

RICK, C.M. and SAWANT, A.C. (1955). Factor interactions affecting the phenotypic expression of the jointless character in tomatoes. Amer. Soc. Hort. Sci. 66: 354-360.

ROBLES, P. and PELAZ, S. (2005). Flower and fruit development in Arabidopsis thaliana. Int. J. Dev. Biol. 49: 633-643.

ROSS, J.J., O'NEILL, D.P., SMITH, J.J., KERCKHOFFS, L.H.J. and ELLIOTT, R.C. (2000). Evidence that auxin promotes gibberellin A1 biosynthesis in pea. Plant Journal 21: 547-552.

SAMACH, A. and LOTAN, H. (2007). The transition to flowering in tomato. Plant Biotechnology 24: 71-82.

SAWHNEY, V.K. (1992). Floral mutants in tomato: development, physiology and evolutionary implications. Can. J. Bot. 70: 701-707.

SAWHNEY, V.K. and SHUKLA, A. (1994). Male sterility in flowering plants: Are plant growth substances involved?. Am. J. Bot. 81: 1640-1647.

SCHMITZ, G., TILLMANN, E., CARRIERO, F., FIORE, C., CELLINI, F.M. and THERES, K. (2002). The tomato Blind gene encodes a MYB transcription factor that controls the formation of lateral meristems. Proc. Nat. Acad. Sci. USA 99: 1064-1069.

SCHUMACHER, K., SCHMITT, T., ROSSBERG, M., SCHMITZ, C. and THERES, K. (1999). The Lateral suppressor $(\angle S)$ gene of tomato encodes a new member of the VHIID protein family. Proc. Nat. Acad. Sci. USA 96: 290-295.

SEYMOUR, G.B., MANNING, K., ERIKSSON, E.M., POPOVICH, A.H. and KING, G.J. (2002). Genetic identification and genomic organization of factors affecting fruit texture. J. Exp. Bot. 53: 2065 - 2071.

SORESSI, G.P. and SALAMINI, F. (1975). A monomendelian gene inducing parthenocarpic fruits. Tomato Genetics Cooperative Reports 25: 22.
STUBBE, H. (1963). Mutanten der Kulturtomate Lycopersicon esculentum Millar IV. Kulturpflanze 11: 603-644.

SZYMKOWIAK, E.J. and IRISH, E.E. (2006). JOINTLESS suppresses sympodial identity in inflorescence meristems of tomato. Planta 223: 646-658.

TANKSLEY, S.D. (2004). The genetic, developmental, and molecular bases of fruit size and shape variation in tomato. Plant Cel/ 16: S181-S189.

THOMPSON, A.J., TOR, M., BARRY, C.S., VREBALOV, J., ORFILA, C., JARVIS, M.C., GIOVANNONI, J.J., GRIERSON, D. and SEYMOUR, G.B. (1999).'Molecular and genetic characterization of a novel pleiotropic tomato-ripening mutant. Plant Physiology 120: 383-389.

TIGCHELAAR, E.C., McGLASSON, W.B. and BUESCHER R.W. (1978). Genetic regulation of tomato fruit ripening. HortScience 13: 508-513.

VAN DER HOEVEN, R., RONNING, C., GIOVANNONI, J., MARTIN, G. and TANKSLEY, S. (2002). Deductions about the Number, Organization, and Evolution of Genes in the Tomato Genome Based on Analysis of a Large Expressed Sequence Tag Collection and Selective Genomic Sequencing. Plant Cel/ 14: 1441-1456.

VREBALOV, J., RUEZINSKY, D., PADMANABHAN, V., WHITE, R., MEDRANO, D., DRAKE, R., SCHUCH, W. and GIOVANNONI, J. (2002). A MADS-Box gene necessary for fruit ripening at the tomato ripening-inhibitor (Rin) locus. Science 296: 343 - 346.

WEIGEL, D., ALVAREZ, J., SMYTH, D.R., YANOFSKY, M.F. and MEYEROWITZ, E.M. (1992). $\angle E A F Y$ controls floral meristem identity in Arabidopsis. Cel/69: 843-859.

XIAO, H., JIANG, N., SCHAFFNER, E, STOCKINGER, E. J. AND VAN DER KNAAP, E. (2008). A retrotransposon-mediated gene duplication underlies morphological variation of tomato fruit. Science 310: 1527-1530.

YEAGER, A.F. (1927). Determinate growth in tomato. J. Hered. 18: 263-265.

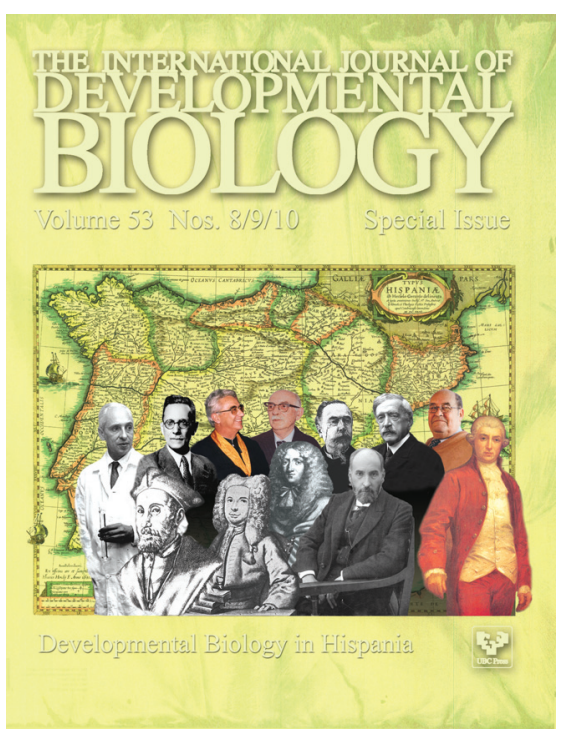


Further Related Reading, published previously in the Int. J. Dev. Biol.

See our recent Special Issue Epigenetics \& Development edited by Saadi Khochbin and Stefan Nonchev at: http://www.ijdb.ehu.es/web/contents.php?vol=53\&issue=2-3

See Special Issue Pattern Formation edited by Michael K. Richardson and Cheng-Ming Chuong at: http://www.ijdb.ehu.es/web/contents.php?vol=53\&issue=5-6

Chromatin remodeling in plant development

José A. Jarillo, Manuel Piñeiro, Pilar Cubas and José M. Martínez-Zapater

Int. J. Dev. Biol. (2009) 53: 1581-1596. (doi: 10.1387/ijdb.072460jj)

Animal reproduction biotechnology in Poland

Zdzislaw Smorag, Lucyna Katska-Ksiazkiewicz, Maria Skrzyszowska, Jacek Jura, Barbara Gajda and Michal Bochenek

Int. J. Dev. Biol. (2008) 52: 151-155

Gametophyte interaction and sexual reproduction: how plants make a zygote

Leonor C. Boavida, Ana Maria Vieira, Jörg D. Becker and José A. Feijó

Int. J. Dev. Biol. (2005) 49: 615-632

Regulation of phyllotaxis

Didier Reinhardt

Int. J. Dev. Biol. (2005) 49: 539-546

Long-range signalling in plant reproductive development

Paula Suárez-López

Int. J. Dev. Biol. (2005) 49: 761-771

Regulated RNA processing in the control of Arabidopsis flowering

Victor Quesada, Caroline Dean and Gordon G. Simpson

Int. J. Dev. Biol. (2005) 49: 773-780

Environmental regulation of flowering

Israel Ausín, Carlos Alonso-Blanco and José-Miguel Martínez-Zapater

Int. J. Dev. Biol. (2005) 49: 689-705

Flowering: a time for integration

François Parcy

Int. J. Dev. Biol. (2005) 49: 585-593

Flower and fruit development in Arabidopsis thaliana

Pedro Robles and Soraya Pelaz

Int. J. Dev. Biol. (2005) 49: 633-643

Different roles of flowering time genes in the activation of floral initiation genes in Arabidopsis. F Madueño, L Ruiz Garcia, M Wilkinson, G Haughn, J Salinas and J Martinez Zapater Int. J. Dev. Biol. (1996) 40: S125-S126

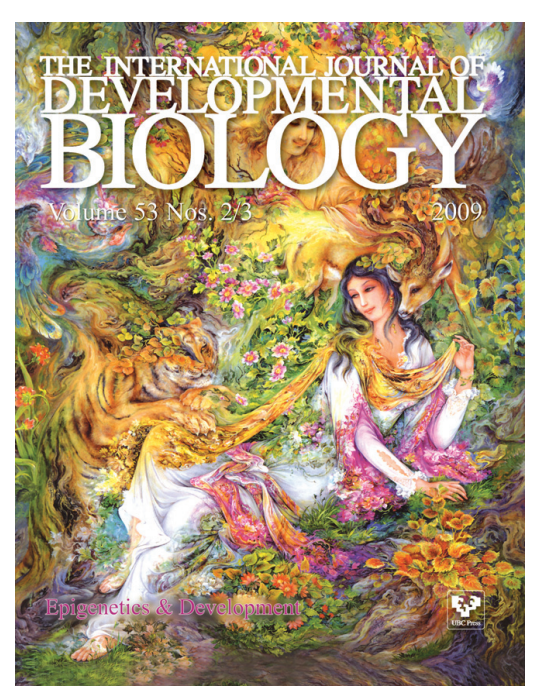

5 yr ISI Impact Factor $(2008)=3.271$

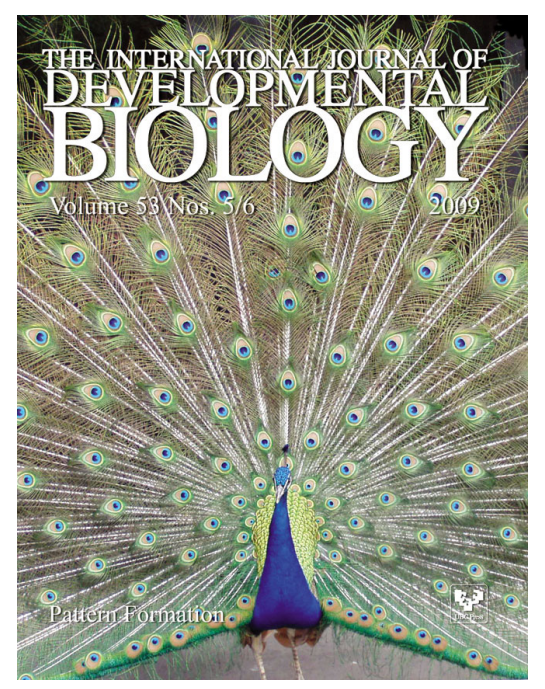

